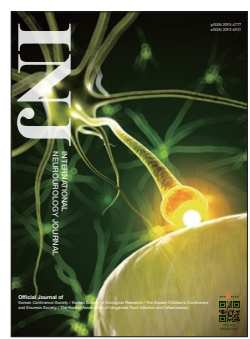

\title{
Knowledge Knows No Boundaries
}

\author{
Tack Lee (iD https://orcid.org/0000-0001-8508-9099 \\ Department of Urology, Inha University Hospital, Incheon, Korea \\ E-mail: lee.tack33@gmail.com
}

Medicine, in its two aspects of being a discipline of practice and a discipline of science, walks a fine and difficult line between the urgent needs of utility and the relaxed curiosity of science. As a practical science, Medicine is limited with a myopic vision imbued on our research by constantly haranguing question of worth, yet also grants great blessing in the form of the most humane of human activities when it is applied to treat those in suffering. Only rarely is the medical scientist free from the question of utility and allowed to pursue discovery purely for the goal of knowledge.

There is no doubt that no medical scientist could claim steadfast that either of these viewpoints should be held against the other. The most unexpected discoveries or breakthroughs are often provided by insights that had been born of an entirely unrelated need. Yet, while it is romantic to imagine a medical scientist completely divorced from the urgent needs of patients at hand, focused erudite and lofty research is seldom at our leisure.

Hence, it might be more important for the medical researcher to cast her net far and wide and recruiting various disciplines to aid and assist in solving medical problems. With a firm grasp on medical problems, the neurourologist can find many allies willing to help by applying their particular field of expertise to solve our problems. The International Neurourology Journal (INJ) has always strived for expanding our horizon in these fields. Whether we published articles on new experimental research technologies [1], application of new technologies to medicine [2-6], or expanding our focus through more emphasis on neurology than urology $[7,8]$, the INJ has never forgotten its mission as a translational re- search publication.

In pre-modern times, national borders often dictated the limits to our knowledge. Science and technology faced discrepancies at similar geographic delineations as shared by political or ideological. But in modern times, knowledge is no longer limited by such paltry squabbles. Instead, perhaps more shamefully, it is limited by ignorance and lack of imagination, a fault entirely which we can blame on no other.

Hence, it is demanded of us as medical scientists to investigate beyond our comfort zone, reach out to specialists in other fields. And when the neurourologists wants to finds her unorthodox solution, the INJ will be there to help.

- Conflict of Interest: No potential conflict of interest relevant to this article was reported.

\section{REFERENCES}

1. Lee NY. Recent progress in lab-on-a-chip technology and its potential application to clinical diagnoses. Int Neurourol J 2013;17:210.

2. Kim J. Era of the fourth industrial revolution and the urologists' journey to navigating big omics data. Int Neurourol J 2018; 22(Suppl 2): S101-2.

3. Setiawati A, Nguyen HT, Jung Y, Shin K. Future research directions in the design of versatile extracellular matrix in tissue engineering. Int Neurourol J 2018;22(Suppl 2):S66-75. 
4. Whangbo TK, Eun SJ, Jung EY, Park DK, Kim SJ, Kim CH, et al. Personalized urination activity recognition based on a recurrent neural network using smart band. Int Neurourol J 2018;22(Suppl 2):S91-100.

5. Kim SE, Ko IG, Ji ES, Jin JJ, Hwang L, Kim SH, et al. Treadmill exercise alleviates circadian rhythm disruption-induced memory deficits by activation of glucocorticoid receptor and brain-derived neurotrophic factor-dependent pathway. Int Neurourol J 2019;23(Suppl 1):S40-9.

6. Park SS, Park HS, Jeong H, Kwak HB, No MH, Heo JW, et al.
Treadmill exercise ameliorates chemotherapy-induced muscle weakness and central fatigue by enhancing mitochondrial function and inhibiting apoptosis. Int Neurourol J 2019;23(Suppl 1):S32-9.

7. Cho CH, Byun HR, Jover-Mengual T, Pontarelli F, Dejesus C, Cho $\mathrm{AR}$, et al. Gadd45b acts as neuroprotective effector in global ischemiainduced neuronal death. Int Neurourol J 2019;23(Suppl 1):S11-21.

8. Kim C). Mitochondrial dysfunction as a cause of neurological diseases. Int Neurourol J 2019;23(Suppl 1):S3-4. 